\title{
Clinical Characteristics of Liver Metastasis in Nivolumab- treated Patients with Non-small Cell Lung Cancer
}

\author{
TAKAYUKI SHIROYAMA ${ }^{1,2}$, HIDEKAZU SUZUKI $^{1}$, MOTOHIRO TAMIYA $^{3}$, AKIHIRO TAMIYA $^{4}$, \\ AYAKO TANAKA ${ }^{1}$, NORIO OKAMOTO ${ }^{1}$, KENJI NAKAHAMA ${ }^{4}$, YOSHIHIKO TANIGUCHI ${ }^{4}$, SHUN-ICHI ISA $^{5}$, \\ TAKAKO INOUE $^{3}$, FUMIO IMAMURA ${ }^{3}$, SHINJI ATAGI ${ }^{5}$ and TOMONORI HIRASHIMA ${ }^{1}$ \\ ${ }^{I}$ Department of Thoracic Oncology, Osaka Habikino Medical Center, Osaka, Japan; \\ ${ }^{2}$ Department of Respiratory Medicine and Clinical Immunology, \\ Graduate School of Medicine, Osaka University, Osaka, Japan; \\ ${ }^{3}$ Department of Thoracic Oncology, Osaka International Cancer Institute, Osaka, Japan; \\ ${ }^{4}$ Department of Internal Medicine, Kinki-chuo Chest Medical Center, Osaka, Japan; \\ ${ }^{5}$ Department of Clinical Research Center, Kinki-chuo Chest Medical Center, Osaka, Japan
}

\begin{abstract}
Background: Recent studies have revealed that liver metastasis is associated with poor outcomes after treatment using immune checkpoint inhibitors, although the cause remains unclear. Patients and Methods: We retrospectively identified 201 patients at three Japanese Centers who received nivolumab for advanced non-small cell lung cancer between December 2015 and July 2016. The patients' baseline clinical characteristics and subsequent outcomes were compared according to liver metastasis status. Results: Liver metastasis was associated with inferior progression-free survival (PFS) and a lower response rate. Additionally, liver metastasis was significantly associated with younger age, poorer Eastern Cooperative Oncology Group performance status (ECOG PS), and more metastatic sites. Multivariate analyses revealed that poor PFS was independently associated with poor baseline ECOG PS $(p=0.039)$ and high number of metastatic sites $(p=0.007)$, although liver metastasis $(p=0.2)$ was not. Conclusion: Baseline clinical characteristics were a strong predictor of outcome in nivolumab-treated patients with liver metastasis.
\end{abstract}

Immunotherapy has led to major breakthroughs in cancer treatment. For example, nivolumab is a fully humanized immunoglobulin G4 antibody that inhibits programmed

Correspondence to: Takayuki Shiroyama, MD, Department of Respiratory Medicine and Rheumatic DiseasesClinical Immunology, Graduate School of Medicine, Osaka University, Osaka, Japan. Tel: +81 68775111, e-mail: takayuki.s12@hotmail.co.jp

Key Words: Nivolumab, immune checkpoint inhibitor, liver metastasis, non-small cell lung cancer, neutrophil-to-lymphocyte ratio, NLR. death-1 (PD-1), which is a T-cell checkpoint receptor protein, by disrupting the interaction between PD-1 and its ligands (PD-L1 and PD-L2). Two key phase III studies $(1,2)$ demonstrated that nivolumab improved overall survival among up to $20 \%$ of patients who were previously treated for advanced non-small cell lung cancer (NSCLC).

Liver metastasis is a well-known negative prognostic factor among patients with NSCLC $(3,4)$. Although its definite cause remains unclear, liver metastasis also predicts poor outcomes after chemotherapy, including treatment using epidermal growth factor receptor tyrosine kinase inhibitors $(5,6)$. In addition, many recent studies have indicated that liver metastasis is associated with poor outcomes after treatment using immune checkpoint inhibitors (7-12). This phenomenon may involve liver metastasis causing reduced marginal $\mathrm{CD}^{+}$T-cell infiltration at the invasive tumor margin, which was observed among patients with melanoma and liver metastasis who were treated using pembrolizumab (8). However, it remains unclear why poor clinical outcomes are associated with liver metastasis among patients with NSCLC who received nivolumab, due to the lack of studies that have examined the characteristics of this patient population. Therefore, we hypothesized that patient-related factors (e.g. blood markers) might influence the response of advanced NSCLC to nivolumab and retrospectively analyzed a multicenter group of patients to test this hypothesis.

\section{Materials and Methods}

Patient selection. This retrospective multicenter study evaluated patients with previously treated advanced NSCLC who started nivolumab treatment ( $3 \mathrm{mg} / \mathrm{kg}$ intravenously every 2 weeks) at one of three Japanese institutions between December 17, 2015 (the date nivolumab was approved in Japan) and July 31, 2016. Patients were excluded if they received nivolumab as part of a clinical trial or 
Table I. Baseline patient characteristics according to liver metastasis status.

\begin{tabular}{|c|c|c|c|}
\hline Characteristic & $\begin{array}{c}\text { Liver } \\
\text { metastasis } \\
(\mathrm{n}=29)\end{array}$ & $\begin{array}{l}\text { No liver } \\
\text { metastasis } \\
(\mathrm{n}=172)\end{array}$ & $p$-Value \\
\hline Median age (range), years & $65(27-85)$ & $68.5(45-87)$ & 0.044 \\
\hline Gender, n (\%) & & & 0.53 \\
\hline Male & $18(62.1 \%)$ & $117(68.0 \%)$ & \\
\hline Female & $11(37.9 \%)$ & $55(32.0 \%)$ & \\
\hline ECOG performance status, $\mathrm{n}(\%)$ & & & 0.008 \\
\hline $0-1$ & $16(55.2 \%)$ & $137(80.0 \%)$ & \\
\hline $2-4$ & $13(44.8 \%)$ & $35(20.0 \%)$ & \\
\hline Histology, n (\%) & & & 0.62 \\
\hline Squamous & $7(24.1 \%)$ & $34(19.8 \%)$ & \\
\hline Non-squamous & $22(75.9 \%)$ & $138(80.2 \%)$ & \\
\hline Smoking status, $\mathrm{n}(\%)$ & & & 0.81 \\
\hline Never smokers & $7(24.1 \%)$ & $37(21.5 \%)$ & \\
\hline Current or former smokers & $22(75.9 \%)$ & $135(78.5 \%)$ & \\
\hline No. of metastatic sites, $\mathrm{n}(\%)$ & & & 0.014 \\
\hline $0-1$ & $6(20.7 \%)$ & $80(46.5 \%)$ & \\
\hline$\geq 2$ & $23(79.3 \%)$ & $92(53.5 \%)$ & \\
\hline \multicolumn{4}{|l|}{ Clinical benefit } \\
\hline Response rate & $3.4 \%$ & $18.0 \%$ & 0.054 \\
\hline Disease control rate & $31.0 \%$ & $55.2 \%$ & 0.026 \\
\hline
\end{tabular}

ECOG, Eastern Cooperative Oncology Group.

concurrently received any other anticancer therapy. This study's retrospective protocol was approved by the Ethical Review Boards at each participating institution, was registered in the UMIN Clinical Trials Registry (UMIN000025908), and complied with the 1964 Declaration of Helsinki and its later amendments. All patients provided written informed consent before starting nivolumab treatment.

Data collection. The patients' medical records were reviewed to collect data regarding sex, age, Eastern Cooperative Oncology Group performance status (ECOG PS), smoking history, histology, number of metastatic sites at the start of nivolumab treatment, and baseline laboratory findings ( $<2$ weeks before starting nivolumab), which included data regarding complete blood count, C-reactive protein (CRP), serum albumin, lactate dehydrogenase (LDH), and the neutrophil-to-lymphocyte ratio (NLR). Response to nivolumab was determined using version 1.1 of the Response Evaluation Criteria in Solid Tumors (13). Dates of tumor progression, death, or the last follow-up were also determined. All clinical data were confirmed by an independent contract research organization (EPSOGO Co., Ltd., Tokyo, Japan) and the cut-off date for data collection was October 31, 2017.

Statistical analysis. Based on a previous report regarding prognostic factors for patients with nivolumab-treated NSCLC, the cut-off value for NLR was defined as 5 (9). The cut-off values for other continuous variables were defined using their median values or the upper limit of normal. Survival curves were analyzed using the Kaplan-Meier method and the log-rank test. Progression-free survival (PFS) was assessed from the first day of treatment with nivolumab to the disease progression or death from any cause. Univariate and multivariate analyses were performed using Cox
Table II. Associations of liver metastasis with blood markers. Data are median (range) values.

\begin{tabular}{lccc}
\hline Marker & $\begin{array}{c}\text { Liver } \\
\text { metastasis } \\
(\mathrm{n}=29)\end{array}$ & $\begin{array}{c}\text { No liver } \\
\text { metastasis } \\
(\mathrm{n}=172)\end{array}$ & $p$-Value \\
\hline $\mathrm{CRP}, \mathrm{mg} / \mathrm{dl}$ & $1.74(0.08-23.6)$ & $0.59(0.01-30.3)$ & 0.003 \\
$\mathrm{ALB}, \mathrm{g} / \mathrm{d} l^{*}$ & $3.5(2.3-4.8)$ & $3.7(2.1-4.9)$ & 0.26 \\
LDH, IU/l & $324(145-1,880)$ & $209(120-1,193)$ & $<0.001$ \\
Neutrophil count, $\mathrm{n} / \mu \mathrm{l}$ & $5,666(2,349-$ & $4,146(1,136-$ & \\
& $12,850)$ & $19,790)$ & 0.037 \\
Lymphocyte count, $\mathrm{n} / \mu 1$ & $954(140-1,962)$ & $1,310(266-4,889)$ & $<0.001$ \\
NLR & $6.0(1.6-52.3)$ & $3.1(0.7-71.4)$ & $<0.001$ \\
\hline
\end{tabular}

CRP, C-Reactive protein; ALB, albumin; LDH, lactate dehydrogenase; NLR, neutrophil-to-lymphocyte ratio. *Data were unavailable in 11 cases.

proportional hazard models. Continuous variables were analyzed using the Mann-Whitney $U$-test, while categorical variables were analyzed using Fisher's exact test. All $p$-values were based on the two-sided hypothesis and considered statistically significant at less than 0.05 . All statistical analyses were performed using R software (version 3.3.2). Multivariate analysis was performed to determine whether the presence of liver metastasis independently predicted PFS. Most characteristics with a univariate $p$-value of less than 0.05 were included in the multivariate analysis, although we planned to omit neutrophil and lymphocyte counts from the multivariate analysis if NLR was a stronger predictor of survival, given that NLR is calculated using the neutrophil and lymphocyte counts.

\section{Results}

Associations of liver metastasis with patient characteristics. During the study period, 201 patients we identified who received nivolumab for previously treated advanced NSCLC, including 29 patients $(14.1 \%)$ with liver metastases at the start of nivolumab treatment. Table I shows the patients' baseline characteristics according to their liver metastasis status. Patients with liver metastases were significantly younger (65 years $v s$. 68.5 years, $p=0.044$ ), had significantly poorer baseline ECOG PS (PS $\geq 2$ : $44.8 \%$ vs. $20.0 \%, p<0.001$ ), and had significantly more metastatic sites $(p=0.014)$. Among the laboratory findings (CRP, serum albumin, LDH, neutrophil count, lymphocyte count, and NLR), only serum albumin was not significantly worse among patients with liver metastases (Table II).

Treatment outcomes. Among all 201 patients, the response rate to nivolumab was $15.9 \%$ and the disease control rate was $51.7 \%$. Among the 29 patients with liver metastasis, the response rate was $3.4 \%$, which was noticeably lower than that among patients without liver metastasis $(18.0 \%$, $p=0.054)$. Patients with liver metastasis had a significantly lower disease control rate than patients without $(31.0 \%$ vs. $55.2 \%, p=0.026$ ) (Table I). 
Table III. Predictors of progression-free survival in the univariate and multivariate analyses.

\begin{tabular}{|c|c|c|c|c|}
\hline \multirow[b]{2}{*}{ Factor } & \multicolumn{2}{|c|}{ Univariate analysis } & \multicolumn{2}{|c|}{ Multivariate analysis } \\
\hline & $\mathrm{HR}(95 \% \mathrm{CI})$ & $p$-Value & $\mathrm{HR}(95 \% \mathrm{CI})$ & $p$-Value \\
\hline Age $<75$ years & $1.28(0.89-1.89)$ & 0.21 & & \\
\hline ECOG PS $\geq 2$ & $1.83(1.29-2.61)$ & 0.004 & $1.49(1.02-2.16)$ & 0.039 \\
\hline Liver metastasis & $2.07(1.33-3.22)$ & 0.001 & $1.38(0.84-2.26)$ & 0.2 \\
\hline Metastatic sites $\geq 2$ & $1.80(1.30-2.49)$ & $<0.001$ & $1.59(1.14-2.23)$ & 0.007 \\
\hline $\mathrm{CRP}>0.3 \mathrm{mg} / \mathrm{dl}$ & $1.27(0.91-1.78)$ & 0.16 & & \\
\hline $\mathrm{LDH}>240 \mathrm{IU} / 1$ & $1.55(1.12-2.13)$ & 0.007 & $1.37(0.98-1.92)$ & 0.067 \\
\hline Neutrophil count $>4,150 / \mu 1$ & $1.34(0.98-1.83)$ & 0.069 & & \\
\hline Lymphocyte count $<1,290 / \mu 1$ & $1.47(1.07-2.01)$ & 0.017 & & \\
\hline$N L R \geq 5$ & $1.59(1.14-2.21)$ & 0.006 & $1.35(0.94-1.93)$ & 0.099 \\
\hline
\end{tabular}

HR, Hazard ratio; CI, confidence interval; ECOG PS, Eastern Cooperative Oncology Group performance status; CRP, C-reactive protein; LDH, lactate dehydrogenase; NLR, neutrophil-to-lymphocyte ratio.

The median PFS patients overall was 2.9 months $(95 \%$ confidence interval=2.1-3.6 months), and liver metastasis was associated with significantly inferior PFS (1.2 months vs. 3.3 months, $p<0.001$ ) (Figure 1). In the univariate analyses, inferior PFS was significantly associated with an ECOG PS of 2 or more, the presence of liver metastasis, a greater number of metastatic sites, high LDH level, low lymphocyte count, and high NLR. Multivariate analyses revealed that inferior PFS was independently associated with poor baseline ECOG PS $(p=0.039)$ and more metastatic sites $(p=0.007)$, while elevated values for LDH $(p=0.067)$ and NLR $(p=0.099)$ tended to have a stronger negative effect than the presence of liver metastasis $(p=0.2)$ (Table III).

\section{Discussion}

This study investigated the clinical characteristics of liver metastasis in patients with NSCLC who received nivolumab. Among these patients, liver metastasis was significantly associated with younger age, poorer ECOG PS, and more metastatic sites. Multivariate analyses revealed that PFS after nivolumab treatment was independently associated with poor baseline ECOG PS and a greater number of metastatic sites, while elevated values for LDH and NLR tended to have a greater negative effect than liver metastasis. It is understandable that these factors have a greater influence on the response to nivolumab, as they more strongly influence response to immunotherapy than to other anticancer drugs, given that cancer-associated inflammation plays a key role in both cancer development and the response to immunotherapy (14). In addition, these factors are known to be associated with a poor prognosis after treatment using immune checkpoint inhibitors $(9,15-17)$.

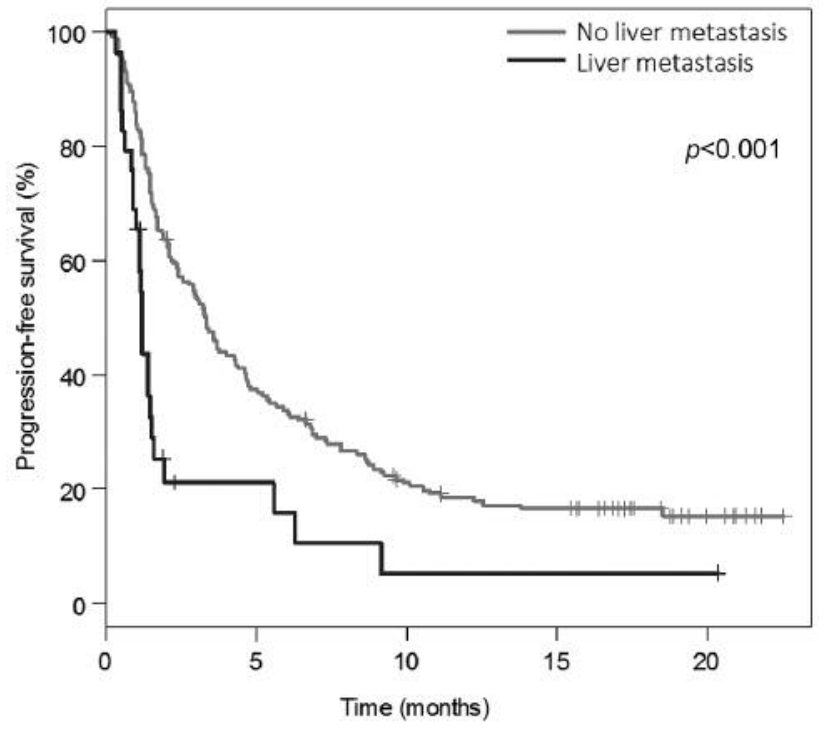

Figure 1. Kaplan-Meier curves for progression-free survival according to liver metastasis status.

Liver metastasis is common among patients with NSCLC, although a retrospective analysis of 23,000 patients with lung cancer and distant metastasis in the Surveillance, Epidemiology, and End Results database revealed that a single distant metastasis was less common than brain or bone metastases from NSCLC (4). Furthermore, especially for adenocarcinoma, fewer than $10 \%$ of patients had a single liver metastasis (4), which indicates that there is a high likelihood that multiple metastases have already developed by the time liver metastasis is actually detected. This is consistent with our findings, which revealed that patients with liver metastasis had 


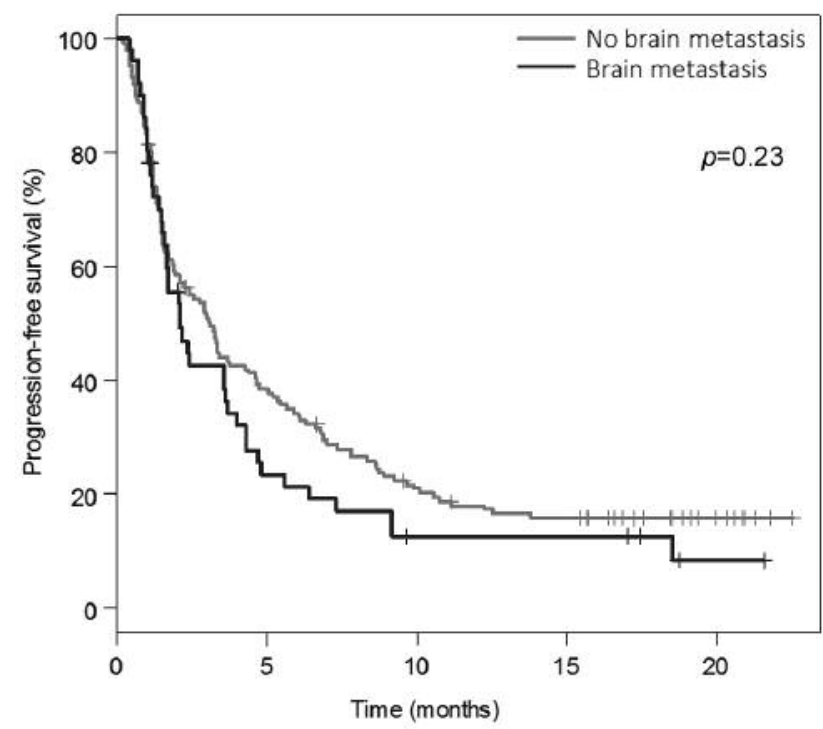

Figure 2. Kaplan-Meier curves for progression-free survival according to brain metastasis status.

a significantly higher number of metastatic sites. Furthermore, it is logical to assume that patients with multiple metastatic sites would have a poorer ECOG PS and higher NLR than patients with early-stage disease, which might explain the poor response to nivolumab among patients with NSCLC and liver metastasis. The 3-year updated data from the CheckMate 017 and 057 trials were recently reported (10), and also revealed that patients with liver metastasis had a greater number of metastatic sites than the cohort overall, with only $3 \%$ of patients (7/193) having liver metastasis as a single distant metastasis. Nevertheless, the 3-year updated data revealed a survival benefit for patients treated with nivolumab ( $v s$. docetaxel) among patients with NSCLC and liver metastasis (hazard ratio $(\mathrm{HR})=0.68,95 \%$ confidence interval $(\mathrm{CI})=0.50$ $0.91)$ (10). These results suggest that nivolumab treatment has sufficient therapeutic effects among all patients with NSCLC, regardless of liver metastasis, although improved outcomes from nivolumab treatment may be observed among patients with liver metastasis and few metastatic sites, a good ECOG PS, or a low NLR.

A recent study of melanoma biopsy samples from patients who received pembrolizumab revealed that $\mathrm{CD} 8^{+} \mathrm{T}-$-cell counts at the invasive margins of distant tumors were associated with treatment response among patients with liver metastasis (8). In this context, the liver helps maintain the local immune microenvironment and liver-induced peripheral tolerance may influence treatment outcomes. Although the so-called 'liver tolerance effect' (18) leads to better outcomes in the field of liver transplantation, immunotherapy targeting the liver may also be influenced
Table IV. Baseline patient characteristics according to brain metastasis status.

\begin{tabular}{|c|c|c|c|}
\hline Characteristic & $\begin{array}{c}\text { Brain } \\
\text { metastasis } \\
(\mathrm{n}=51)\end{array}$ & $\begin{array}{l}\text { No brain } \\
\text { metastasis } \\
(\mathrm{n}=150)\end{array}$ & $p$-Value \\
\hline Median age (range), years & $66(45-85)$ & $69(27-87)$ & 0.1 \\
\hline Gender, n (\%) & & & 0.17 \\
\hline Male & $30(58.8 \%)$ & $105(70.0 \%)$ & \\
\hline Female & $21(41.2 \%)$ & $45(30.0 \%)$ & \\
\hline ECOG performance status, $\mathrm{n}(\%)$ & & & 0.087 \\
\hline $0-1$ & $34(66.7 \%)$ & $119(79.3 \%)$ & \\
\hline $2-4$ & $17(33.3 \%)$ & $31(20.7 \%)$ & \\
\hline Histology, n (\%) & & & 0.69 \\
\hline Squamous & $9(17.6 \%)$ & $32(21.3 \%)$ & \\
\hline Non-squamous & $42(82.4 \%)$ & $118(78.7 \%)$ & \\
\hline Smoking status, $\mathrm{n}(\%)$ & & & 0.33 \\
\hline Never smokers & $14(27.5 \%)$ & $30(20.0 \%)$ & \\
\hline Current or former smokers & $37(72.5 \%)$ & $120(80.0 \%)$ & \\
\hline No. of metastatic sites, $\mathrm{n}(\%)$ & & & $<0.001$ \\
\hline $0-1$ & $6(11.8 \%)$ & $80(53.3 \%)$ & \\
\hline$\geq 2$ & $45(88.2 \%)$ & $70(46.7 \%)$ & \\
\hline \multicolumn{4}{|l|}{ Clinical benefit } \\
\hline Response rate & 15 . & & 1 \\
\hline Disease control rate & $48.1 \%$ & $53.3 \%$ & 0.52 \\
\hline
\end{tabular}

ECOG, Eastern Cooperative Oncology Group.

by its immune tolerance. Nevertheless, nivolumab provided durable responses among patients with advanced hepatocellular carcinoma in the CheckMate 040 study (19). Moreover, that study revealed a response rate of approximately $20 \%$, which is similar to the response rates in CheckMate 017 for squamous cell NSCLC (1) and CheckMate 057 for non-squamous cell NSCLC (2). The precise mechanism for this discrepancy remains unclear, although it may be explained by differences in tumor biology, as hepatocellular carcinoma is most commonly attributed to chronic viral infection (e.g. hepatitis B or C) (20).

Another possible explanation for the poor outcomes among nivolumab-treated patients with liver metastasis is mutation heterogeneity of tumor, as the mutation profiles can differ between the primary and metastatic tumor sites (21). Reports have indicated that new clinically actionable mutations can be detected in brain metastases but not in the primary lesions $(22,23)$. A similar phenomenon has been suggested for liver metastasis, although we did not test for mutation heterogeneity in liver biopsy specimens as part of the present study. Among patients with lung cancer, both liver metastasis and brain metastasis are considered prognostic factors. However, we evaluated patients with brain metastasis in the present study, and failed to detect significant differences in their treatment outcomes and clinical characteristics (Figure 2 and Tables IV and V). 
Table V. Associations of brain metastasis with blood markers. Data are median (range) values.

\begin{tabular}{|c|c|c|c|}
\hline Marker & $\begin{array}{c}\text { Brain } \\
\text { metastasis } \\
(\mathrm{n}=51)\end{array}$ & $\begin{array}{l}\text { No brain } \\
\text { metastasis } \\
(\mathrm{n}=150)\end{array}$ & $p$-Value \\
\hline $\mathrm{CRP}, \mathrm{mg} / \mathrm{dl}$ & $0.86(0.01-30.3)$ & $0.65(0.01-23.6)$ & 0.58 \\
\hline $\mathrm{ALB}, \mathrm{g} / \mathrm{dl} \mathbf{l}^{*}$ & $3.5(2.1-4.9)$ & $3.9(2.1-4.8)$ & 0.2 \\
\hline LDH, IU/1 & $232(127-740)$ & $213(120-1,880)$ & 0.37 \\
\hline Neutrophil count, $\mathrm{n} / \mu \mathrm{l}$ & $\begin{array}{c}4,147(1,480- \\
17,020)\end{array}$ & $\begin{array}{c}4,192(1,136- \\
19,790)\end{array}$ & 0.74 \\
\hline Lymphocyte count, $\mathrm{n} / \mu \mathrm{l}$ & $\begin{array}{c}1,190(250- \\
4,889)\end{array}$ & $\begin{array}{c}1,301(140- \\
2,740)\end{array}$ & 0.26 \\
\hline NLR & $3.4(1.1-16.4)$ & $3.2(0.7-71.4)$ & 0.34 \\
\hline
\end{tabular}

CRP, C-Reactive protein; ALB, albumin; LDH, lactate dehydrogenase; NLR, neutrophil-to-lymphocyte ratio. *Data were unavailable in 11 cases.

The present study has several limitations. Firstly, its retrospective design is associated with risks of bias and difficulty generalizing the findings. Secondly, it remains unclear whether our findings are the cause or the effect of the response to nivolumab treatment. Thirdly, many mechanisms affect liver tolerance, including activation of regulatory T-cells by Kupffer cells (24) and up-regulation of PD-L1 expression on myeloid-derived Kupffer cells by hepatitis viruses (25), which makes it difficult to draw definitive conclusions. Finally, we were not able to incorporate PD-L1 status into our analyses, as those data were not collected.

In conclusion, we found that patients with liver metastasis were more likely to be younger, have poorer ECOG PS, have more metastatic sites, and have elevated values for LDH and NLR, relative to patients without liver metastasis. These characteristics were also associated with inferior outcomes among patients who received nivolumab for NSCLC and liver metastasis in clinical practice. Nevertheless, nivolumab treatment had some therapeutic effects in this setting, which precludes the omission of nivolumab treatment for patients with NSCLC merely because they have liver metastasis. Further studies are needed to examine the underlying mechanisms for this relationship and to identify the optimal treatment strategies for patients with NSCLC and liver metastasis.

\section{Conflicts of interest}

T. Shiroyama received grants and lecture fees from Ono Pharmaceutical and grants from Bristol-Myers Squibb during the study, as well as lecture fees from Taiho Pharmaceutical, Boehringer Ingelheim, and AstraZeneca that were unrelated to the submitted work. H. Suzuki received grants and lecture fees from Ono Pharmaceutical and grants from Bristol-Myers Squibb during the study, as well as lecture fees from Taiho Pharmaceutical, Boehringer Ingelheim, Pfizer, and Eli-Lilly that were unrelated to the submitted work. M. Tamiya received grants and lecture fees from Ono Pharmaceutical and grants from Bristol-
Myers Squibb during the study, as well as lecture fees from Chugai Pharmaceutical, Pfizer, AstraZeneca, Taiho Pharmaceutical, Eli Lilly, Asahi Kasei Pharmaceutical, Daichi Sankyo CO. LTD., and Alere Medical that were unrelated to the submitted work. A. Tamiya received grants and lecture fees from Ono Pharmaceutical and Bristol-Myers Squibb during the study, as well as lecture fees from Chugai Pharmaceutical, AstraZeneca, Eli Lilly, and Boehringer Ingelheim that were unrelated to the submitted work. A. Tanaka received grants and lecture fees from Ono Pharmaceutical and grants from Bristol-Myers Squibb during the study, as well as lecture fees from Siemens and Chugai Pharmaceutical that were unrelated to the submitted work. N. Okamoto received grants from Ono Pharmaceutical and Bristol-Myers Squibb during the study, as well as lecture fees from AstraZeneca that were unrelated to the submitted work. K. Nakahama received grants from Ono Pharmaceutical and Bristol-Myers Squibb during the study. Y. Taniguchi received grants from Ono Pharmaceutical and BristolMyers Squibb during the study, as well as lecture fees from Chugai Pharmaceutical that were unrelated to the submitted work. S. Isa received grants from Ono Pharmaceutical and Bristol-Myers Squibb during the study. T. Inoue received grants and lecture fees from Ono Pharmaceutical and grants from Bristol-Myers Squibb during the study, as well as lecture fees from Boehringer Ingelheim that were unrelated to the submitted work. F. Imamura received grants and lecture fees from Ono Pharmaceutical and Bristol-Myers Squibb during the study, as well as lecture fees from Pfizer Inc., AstraZeneca K. K., Novartis Pharma K. K. Kyowa Hakko Kirin Co. Ltd., Boehringer Ingelheim, Taiho Pharmaceutical Co. Ltd., Eli Lilly Japan K. K., and Chugai Pharmaceutical Co. Ltd. that were unrelated to the submitted work. S. Atagi received grants and lecture fees from Ono Pharmaceutical and Bristol-Myers Squibb during the study, as well as grants from Pfizer, Chugai Pharmaceutical, AstraZeneca, Taiho Pharmaceutical, Yakult Pharmaceutical Industry, MSD, Eli Lilly, and Boehringer Ingelheim, in addition to lecture fees from Taiho Pharmaceutical, Chugai Pharmaceutical, AstraZeneca, Eli Lilly, and Boehringer Ingelheim that were unrelated to the submitted work. T. Hirashima received grants and lecture fees from Ono Pharmaceutical and Bristol-Myers Squibb during the study, as well as grants and lecture fees from MSD Oncology, AstraZeneca, Eli Lilly Japan, Chugai Pharma, and Boehringer Ingelheim, in addition to grants from Eisai, Daiichi Sankyo, Merck Serono, Taiho Pharmaceutical, Kyowa Hakko Kirin, and Takeda, plus lecture fees from Bayer, that were unrelated to the submitted work.

\section{Ethical approval}

All study procedures complied with the ethical standards of the institutional and/or national research committees and with the 1964 Helsinki declaration and its later amendments.

\section{Informed Consent}

All patients provided written informed consent for the treatment using nivolumab.

\section{Funding}

This study was supported by Ono Pharmaceutical Co., Ltd. and Bristol-Myers Squibb, although these sponsors played no role in the study design, data collection and analysis, decision to publish, or preparation of the article. 


\section{Acknowledgements}

The Authors thank all the patients and investigators who participated in this study.

\section{References}

1 Brahmer J, Reckamp KL, Baas P, Crino L, Eberhardt WE, Poddubskaya E, Antonia S, Pluzanski A, Vokes EE, Holgado E, Waterhouse D, Ready N, Gainor J, Aren Frontera O, Havel L, Steins M, Garassino MC, Aerts JG, Domine M, Paz-Ares L, Reck M, Baudelet C, Harbison CT, Lestini B and Spigel DR: Nivolumab versus docetaxel in advanced squamous-cell nonsmall-cell lung cancer. N Engl J Med 373: 123-135, 2015.

2 Borghaei H, Paz-Ares L, Horn L, Spigel DR, Steins M, Ready NE, Chow LQ, Vokes EE, Felip E, Holgado E, Barlesi F, Kohlhaufl M, Arrieta O, Burgio MA, Fayette J, Lena H, Poddubskaya E, Gerber DE, Gettinger SN, Rudin CM, Rizvi N, Crino L, Blumenschein GR Jr., Antonia SJ, Dorange C, Harbison CT, Graf Finckenstein F and Brahmer JR: Nivolumab versus docetaxel in advanced nonsquamous non-small-cell lung cancer. N Engl J Med 373: 1627-1639, 2015.

3 Riihimaki M, Hemminki A, Fallah M, Thomsen H, Sundquist K, Sundquist $\mathrm{J}$ and Hemminki K: Metastatic sites and survival in lung cancer. Lung Cancer 86: 78-84, 2014.

4 Ren Y, Dai C, Zheng H, Zhou F, She Y, Jiang G, Fei K, Yang P, Xie $\mathrm{D}$ and Chen C: Prognostic effect of liver metastasis in lung cancer patients with distant metastasis. Oncotarget 7: 53245-53253, 2016.

5 Wu KL, Tsai MJ, Yang CJ, Chang WA, Hung JY, Yen CJ, Shen $\mathrm{CH}$, Kuo TY, Lee JY, Chou SH, Liu TC, Chong IW and Huang MS: Liver metastasis predicts poorer prognosis in stage IV lung adenocarcinoma patients receiving first-line gefitinib. Lung Cancer 88: 187-194, 2015.

6 Jiang T, Cheng R, Zhang G, Su C, Zhao C, Li X, Zhang J, Wu F, Chen X, Gao G, Li W, Cai W, Zhou F, Zhao J, Xiong A, Ren S, Zhang G, Zhou C and Zhang J: Characterization of liver metastasis and its effect on targeted therapy in EGFR-mutant NSCLC: a multicenter study. Clin Lung Cancer 18: 631-639, 2017.

7 Funazo T, Nomizo T and Kim YH: Liver metastasis is associated with poor progression-free survival in patients with non-small cell lung cancer treated with nivolumab. J Thorac Oncol 12: e140-e141, 2017.

8 Tumeh PC, Hellmann MD, Hamid O, Tsai KK, Loo KL, Gubens MA, Rosenblum M, Harview CL, Taube JM, Handley N, Khurana N, Nosrati A, Krummel MF, Tucker A, Sosa EV, Sanchez PJ, Banayan N, Osorio JC, Nguyen-Kim DL, Chang J, Shintaku IP, Boasberg PD, Taylor EJ, Munster PN, Algazi AP, Chmielowski B, Dummer R, Grogan TR, Elashoff D, Hwang J, Goldinger SM, Garon EB, Pierce RH and Daud A: Liver metastasis and treatment outcome with anti-PD-1 monoclonal antibody in patients with melanoma and NSCLC. Cancer Immunol Res 5: 417-424, 2017.

9 Bagley SJ, Kothari S, Aggarwal C, Bauml JM, Alley EW, Evans TL, Kosteva JA, Ciunci CA, Gabriel PE, Thompson JC, Stonehouse-Lee S, Sherry VE, Gilbert E, Eaby-Sandy B, Mutale F, DiLullo G, Cohen RB, Vachani A and Langer CJ: Pretreatment neutrophil-to-lymphocyte ratio as a marker of outcomes in nivolumab-treated patients with advanced nonsmall-cell lung cancer. Lung Cancer 106: 1-7, 2017.
10 Vokes EE, Ready N, Felip E, Horn L, Burgio MA, Antonia SJ, Aren Frontera O, Gettinger S, Holgado E, Spigel D, Waterhouse D, Domine M, Garassino M, Chow LQM, Blumenschein G Jr., Barlesi F, Coudert B, Gainor J, Arrieta O, Brahmer J, Butts C, Steins M, Geese WJ, Li A, Healey D and Crino L: Nivolumab versus docetaxel in previously treated advanced non-small cell lung cancer (CheckMate 017 and CheckMate 057): 3-year update and outcomes in patients with liver metastases. Ann Oncol 29: 959-965, 2018.

11 Tournoy KG, Thomeer M, Germonpre P, Derijcke S, De Pauw R, Galdermans D, Govaert K, Govaerts E, Schildermans R, Declercq I, De Brucker N, Pat K, Van Herreweghe R, Van Zandweghe L, Vanmaele L, Van Damme V, Marien H, De Craene S, Fabry I, Alexander P, Vercauter P and Demedts I: Does nivolumab for progressed metastatic lung cancer fulfill its promises? An efficacy and safety analysis in 20 general hospitals. Lung Cancer 115: 49-55, 2018.

12 Tamiya M, Tamiya A, Inoue T, Kimura M, Kunimasa K, Nakahama K, Taniguchi Y, Shiroyama T, Isa SI, Nishino K, Kumagai T, Suzuki H, Hirashima T, Atagi S and Imamura F: Metastatic site as a predictor of nivolumab efficacy in patients with advanced non-small cell lung cancer: a retrospective multicenter trial. PloS One 13: e0192227, 2018.

13 Eisenhauer EA, Therasse P, Bogaerts J, Schwartz LH, Sargent D, Ford R, Dancey J, Arbuck S, Gwyther S, Mooney M, Rubinstein L, Shankar L, Dodd L, Kaplan R, Lacombe D and Verweij J: New Response Evaluation Criteria in Solid Tumours: REVISED RECIST guideline (version 1.1). Eur J Cancer 45: 228-47, 2009.

14 Crusz SM and Balkwill FR: Inflammation and cancer: advances and new agents. Nat Rev Clin Oncol 12: 584-596, 2015.

15 Ferrucci PF, Ascierto PA, Pigozzo J, Del Vecchio M, Maio M, Antonini Cappellini GC, Guidoboni M, Queirolo P, Savoia P, Mandala M, Simeone E, Valpione S, Altomonte M, Spagnolo F, Cocorocchio E, Gandini S, Giannarelli D and Martinoli C: Baseline neutrophils and derived neutrophil-to-lymphocyte ratio: prognostic relevance in metastatic melanoma patients receiving ipilimumab. Ann Oncol 27: 732-738, 2016.

16 Shiroyama T, Suzuki H, Tamiya M, Tamiya A, Tanaka A, Okamoto N, Nakahama K, Taniguchi Y, Isa SI, Inoue $\mathrm{T}$, Imamura F, Atagi S and Hirashima T: Pretreatment advanced lung cancer inflammation index (ALI) for predicting early progression in nivolumab-treated patients with advanced nonsmall cell lung cancer. Cancer Med 7: 13-20, 2018.

17 Nakamura Y, Kitano S, Takahashi A, Tsutsumida A, Namikawa K, Tanese K, Abe T, Funakoshi T, Yamamoto N, Amagai M and Yamazaki N: Nivolumab for advanced melanoma: pretreatment prognostic factors and early outcome markers during therapy. Oncotarget 7: 77404-77415, 2016.

18 Calne RY, Sells RA, Pena JR, Davis DR, Millard PR, Herbertson BM, Binns RM and Davies DA: Induction of immunological tolerance by porcine liver allografts. Nature 223: 472-476, 1969.

19 El-Khoueiry AB, Sangro B, Yau T, Crocenzi TS, Kudo M, Hsu C, Kim TY, Choo SP, Trojan J, Welling THR, Meyer T, Kang YK, Yeo W, Chopra A, Anderson J, Dela Cruz C, Lang L, Neely J, Tang H, Dastani HB and Melero I: Nivolumab in patients with advanced hepatocellular carcinoma (CheckMate 040): an openlabel, non-comparative, phase $1 / 2$ dose escalation and expansion trial. Lancet 389: 2492-2502, 2017.

20 El-Serag HB: Epidemiology of viral hepatitis and hepatocellular carcinoma. Gastroenterology 142: 1264-1273.e1261, 2012. 
21 McGranahan $\mathrm{N}$ and Swanton C: Clonal heterogeneity and tumor evolution: Past, present, and the future. Cell 168: 613-628, 2017.

22 Brastianos PK, Carter SL, Santagata S, Cahill DP, Taylor-Weiner A, Jones RT, Van Allen EM, Lawrence MS, Horowitz PM, Cibulskis K, Ligon KL, Tabernero J, Seoane J, Martinez-Saez E, Curry WT, Dunn IF, Paek SH, Park SH, McKenna A, Chevalier A, Rosenberg M, Barker FG, 2nd, Gill CM, Van Hummelen P, Thorner AR, Johnson BE, Hoang MP, Choueiri TK, Signoretti S, Sougnez C, Rabin MS, Lin NU, Winer EP, StemmerRachamimov A, Meyerson M, Garraway L, Gabriel S, Lander ES, Beroukhim R, Batchelor TT, Baselga J, Louis DN, Getz G and Hahn WC: Genomic characterization of brain metastases reveals branched evolution and potential therapeutic targets. Cancer Discov 5: 1164-1177, 2015.

23 Paik PK, Shen R, Won H, Rekhtman N, Wang L, Sima CS, Arora A, Seshan V, Ladanyi M, Berger MF and Kris MG: Nextgeneration sequencing of stage IV squamous cell lung cancers reveals an association of $\mathrm{PI} 3 \mathrm{~K}$ aberrations and evidence of clonal heterogeneity in patients with brain metastases. Cancer Discov 5: 610-621, 2015.

24 Jenne $\mathrm{CN}$ and Kubes $\mathrm{P}$ : Immune surveillance by the liver. Nat Immunol 14: 996-1006, 2013.

25 Tu Z, Pierce RH, Kurtis J, Kuroki Y, Crispe IN and Orloff MS: Hepatitis $\mathrm{C}$ virus core protein subverts the antiviral activities of human Kupffer cells. Gastroenterology 138: 305-314, 2010.

Received June 14, 2018

Revised June 25, 2018

Accepted June 28, 2018 